\title{
Histopathological study of endometrial lesions in tertiary care hospital
}

\author{
Panchal S. K. ${ }^{1}$, Swami S.Y. ${ }^{2}$, Valand A.G. ${ }^{3}$ \\ ${ }^{1}$ Dr. Shrinivas K. Panchal, Assistant Professor, ${ }^{2}$ Dr. Sunil Y. Swami, Associate Processor, ${ }^{3}$ Dr. Arvind. G. Valand, \\ Professor and Head, all authors are affiliated with Department of Pathology, S. R. T. R. Government Medical College, \\ Ambajogai, Maharashtra. 431517, India.
}

Address for Correspondence: Dr. Sunil Y. Swami. Email:drsys02@gmail.com.

\begin{abstract}
Objective: To study the clinico-pathological aspects and the histo-pathological patterns of endometrial lesions. Methodology: Study includes hysterectomy specimens, dilatation \& curettage samples (D\&C) andbiopsies, received to the department of pathology. Results: Total 542 endometrial samples were received in department of Pathology during September 2013 to September 2015. Out of 542 endometrial samples, 131 are endometrial lesions. Among 131 endometrial lesions, 115 are non-neoplastic while 16 are neoplastic lesions. Most common age group for non-neoplastic lesions is 41-50 years while for neoplastic lesions it is about 51-60 years. Adenomyosis the most common (11.99\%) non-neoplastic lesion while endometrioid adenocarcinoma (46.67\%) ismost common neoplastic lesion. Conclusion:In present study, non- neoplastic lesions were more common out of all endometrial lesions. Among neoplastic lesions malignant lesions were more common than benign lesions; histopathology is important for ensuring diagnosis and deciding management, particularlyfor malignant diseases.
\end{abstract}

Keywords: Histopathology, Endometrium, Lesions, Non-neoplastic, Neoplastic

\section{Introduction}

The internal cavity of the uterus is lined by the endometrium, composed of glands embedded in a cellular stroma[1]. The function of the normal endometrium is to produce a satisfactory substrate in which a healthy blastocyst may implant and flourish [2]. During active reproductive life, the endometrium is in a dynamic state of proliferation, differentiation and shedding, in the preparation for implantation of an embryo. This cycle is exquisitely controlled by the rise and fall of pituitary and ovarian hormones.

Abnormalities in this system result in abnormal uterine bleeding. Various causes of abnormal uterine bleeding are chronic endometritis, endometrial polyps, sub mucosal leiomyoma's and endometrial neoplasms. The largest single group encompasses functional disturbances, referred to as dysfunctional uterine bleeding. "Dating" the endometrium by its histologic appearance is often used clinically to assess hormonal

Manuscript received: $10^{\text {th }}$ October 2017

Reviewed: $20^{\text {th }}$ October 2017

Author Corrected: $28^{\text {th }}$ October 2017

Accepted for Publication: $1^{\text {st }}$ November 2017 status, document ovulation, and determine causes of endometrial bleeding and infertility [1,3]. Endometrial biopsy is a currently preferred alternative to dilatation and curettage $[D \& C]$ for the evaluation of infertile or dysmenorrheic patients.

In addition, this procedure has become the choice method for the initial approach to patients with suspected endometrial hyperplasia or carcinoma [4].

Accurate histopathological diagnosis is important in the management of endometrial conditions and lesions [5].

\section{Material \& Methods}

Type of Study- Prospective observational and descriptive study

Place of study- Department of Pathology, SRTRGMC Ambajogai.

Duration of Study- Two year's duration from $2^{\text {nd }}$ September 2013 to $1^{\text {st }}$ September 2015. 


\section{Original Research Article}

Sample Collection \&Methods- In this study, we will include hysterectomy specimens, dilatation \& curettage samples (D \& C) and biopsies coming to the department of Pathology with various diagnoses like chronic endometritis, hormonal changes in infertility, endometrial polyps, adenomyosis and other benign \& malignant endometrial lesions. Complete clinical history and related investigations will be taken into account according to provided proforma.

Inclusion Criteria: - Histopathological study of Endometrial lesions only.

Exclusion Criteria: - Gestational Trophoblastic diseases \&Myometrial lesions are excluded.

\section{Results}

Clinico-histopathological study of endometrium in 542 cases was done.

Table-1: Distribution of types of surgical specimen received in the present study:

\begin{tabular}{|c|c|c|}
\hline Types of specimen & $\begin{array}{c}\text { Number of } \\
\text { specimens }\end{array}$ & Percentage (\%) \\
\hline Dilatation \& curettage [D\&C] & 130 & 23.98 \\
\hline Hemi hysterectomy & 02 & 0.36 \\
\hline Lower segment caesarean section [LSCS] with hysterectomy & 01 & 0.18 \\
\hline Total abdominal hysterectomy [TAH] & 255 & 47.05 \\
\hline Total vaginal hysterectomy [TVH] & 154 & 28.43 \\
\hline Total & $\mathbf{5 4 2}$ & $\mathbf{1 0 0}$ \\
\hline
\end{tabular}

TAH specimens were the most commonly received specimens, comprising 255 (47.05\%) samples, followed by 154 (28.43\%) TVH samples and $130(23.98 \%)$ D \& C samples. In two cases of uterine didelphi, 2 (0.36\%) hemihysterectomy specimens were received. LSCS followed by hysterectomy comprised only 01 sample $(0.18 \%)$.

Table-2: Clinical presentations in all endometrial lesion cases:

\begin{tabular}{|c|c|c|}
\hline Clinical presentation & No. of cases & Percentage (\%) \\
\hline Increased per vaginal bleeding [PVB] & 343 & 63.28 \\
\hline Mass coming out of vagina & 131 & 24.17 \\
\hline Pain in abdomen & 52 & 2.22 \\
\hline Menorrhagia & 12 & 0.37 \\
\hline White discharge per vagina & 2 & 0.18 \\
\hline Amenorrhea & 1 & 0.18 \\
\hline Irregular bleeding & 1 & $\mathbf{1 0 0}$ \\
\hline Total cases & $\mathbf{5 4 2}$ & \\
\hline
\end{tabular}

The most common clinical presentation was increased PVB, seen in $343(63.28 \%)$ cases followed by mass coming out of vagina in $131(24.17 \%)$ cases, pain in abdomen in $52(9.60 \%)$ cases, menorrhagia in $12(2.22 \%)$ cases, white discharge per vagina in $2(0.37 \%)$ cases and amenorrhea \& irregular bleeding in $1(0.18 \%)$ case each respectively.

Table-3: Cyclical status of endometrium in cases excluding endometrial lesions:

\begin{tabular}{|c|c|c|}
\hline Cyclical phase & No. of Cases & Percentage (\%) \\
\hline Proliferative phase & 151 & 27.86 \\
\hline Secretory phase & 172 & 31.74 \\
\hline Atrophic endometrium & 116 & 21.40 \\
\hline Total cases studied & $\mathbf{5 4 2}$ & \\
\hline
\end{tabular}




\section{Original Research Article}
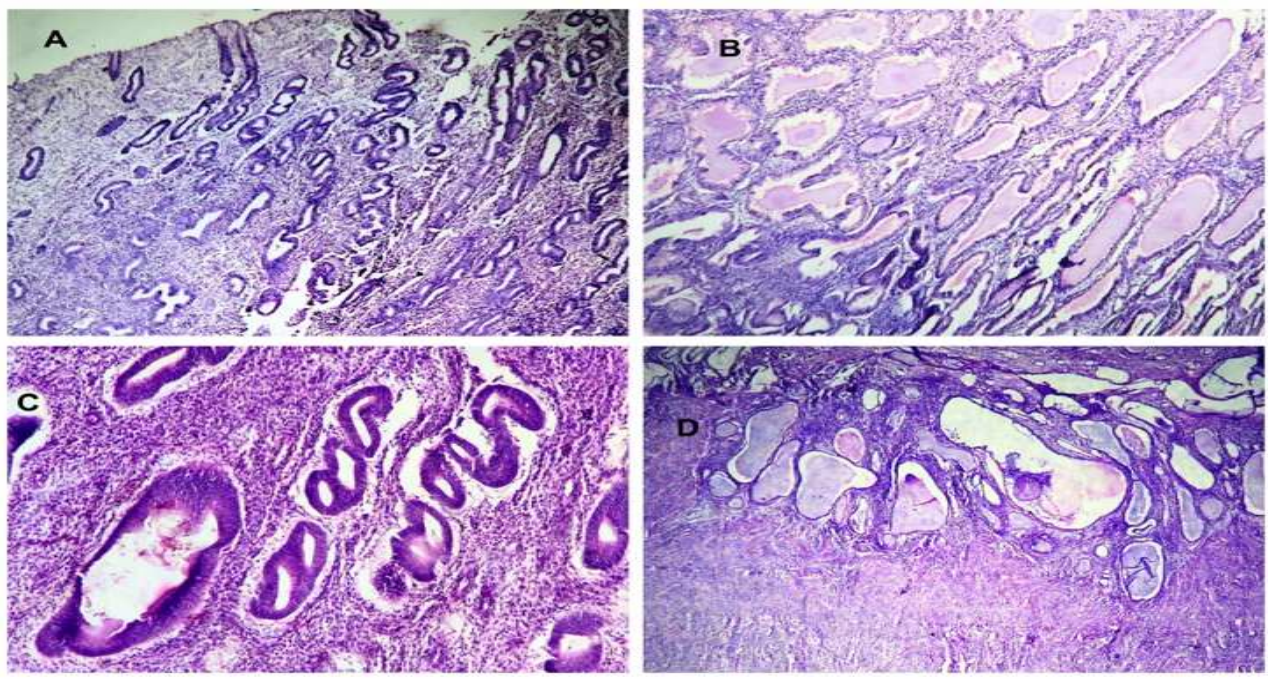

Fig.-1: Cyclical Phases:[H\&E: 10X]

A: Proliferative phase: Tubular \& narrow endometrial glands in compact stroma.

B: Secretory phase: Elongated, dilated, tortuous endometrial glands with secretions.

C: Prolonged oestrogen effect: Endometrial glands with pseudo- stratification of epithelium \& compact stroma.

D: Senile Cystic Atrophy: Cystically dilated atrophic endometrial glands.

Among 542 cases studied, excluding those cases that were not having any cyclical phase, most common cyclical phase observed was the secretory phase [Fig.1: B], seen in 172 (31.74\%) cases followed by proliferative phase [Fig.1: A] in $151(27.86 \%)$ cases. Atrophic endometrium [Fig.1:D] was seen in $116(21.40 \%)$ cases.

Table-4: Distribution of various endometrial lesions:

\begin{tabular}{|c|c|c|}
\hline Type of lesion & No. of lesions & Percentage (\%) \\
\hline Non-neoplastic & 115 & 87.78 \\
\hline Neoplastic & 16 & 12.22 \\
\hline Total no. of lesions & $\mathbf{1 3 1}$ & $\mathbf{1 0 0}$ \\
\hline
\end{tabular}

Among 131 endometrial lesions, 115 (87.78\%) were non-neoplastic lesions \& 16 (12.22\%) were neoplastic lesions.

Table-5: Age wise distribution of non-neoplastic endometrial lesions:

\begin{tabular}{|c|c|c|}
\hline Age in years & No. of lesions & Percentage (\%) \\
\hline $11-20$ & 01 & 0.86 \\
\hline $21-30$ & 04 & 3.47 \\
\hline $31-40$ & 40 & 34.80 \\
\hline $41-50$ & 55 & 47.83 \\
\hline $51-60$ & 12 & 10.44 \\
\hline $61-70$ & 03 & 2.60 \\
\hline & $\mathbf{1 1 5}$ & $\mathbf{1 0 0}$ \\
\hline
\end{tabular}

Non-neoplastic lesions were most commonly seen in the age group 41-50 contributing to $47.83 \%$. 


\section{Original Research Article}

Table-6: Histopathological diagnosis of non- neoplastic lesions:

\begin{tabular}{|c|c|c|}
\hline Histopathological diagnosis & No. of Lesions & Percentage out 542 endometrial lesions (\%) \\
\hline Adenomyosis & 65 & 49.62 \\
\hline Stromal Myosis & 04 & 3.05 \\
\hline Prolonged Oestrogen effect & 01 & 0.76 \\
\hline Predecidual Change & 03 & 2.29 \\
\hline Pill Endometrium & 04 & 3.05 \\
\hline Hormonal Imbalance & 01 & 0.76 \\
\hline Acute Endometritis & 04 & 0.73 \\
\hline Tuberculous Endometritis & 01 & 0.76 \\
\hline Viral Endometritis & 01 & 0.76 \\
\hline Histiocytic Endometritis & 01 & 0.76 \\
\hline Endometrial Polyp & 11 & 8.40 \\
\hline Simple hyperplasia without atypia & 18 & 13.74 \\
\hline Cysto-glandular hyperplasia & 01 & 0.76 \\
\hline Inadequate samples & 38 & 29.0 \\
\hline No. of non-neoplastic lesions & 115 & 87.78 \\
\hline Total no. of endometrial lesions & $\mathbf{1 3 1}$ & \\
\hline
\end{tabular}

Adenomyosis [was observed in $65(11.99 \%)$ cases followed by simple hyperplasia without atypia [Fig.2B] in 18 (3.32\%) cases and endometrial polyp [Fig.2:A] in 11(2.02\%) cases.
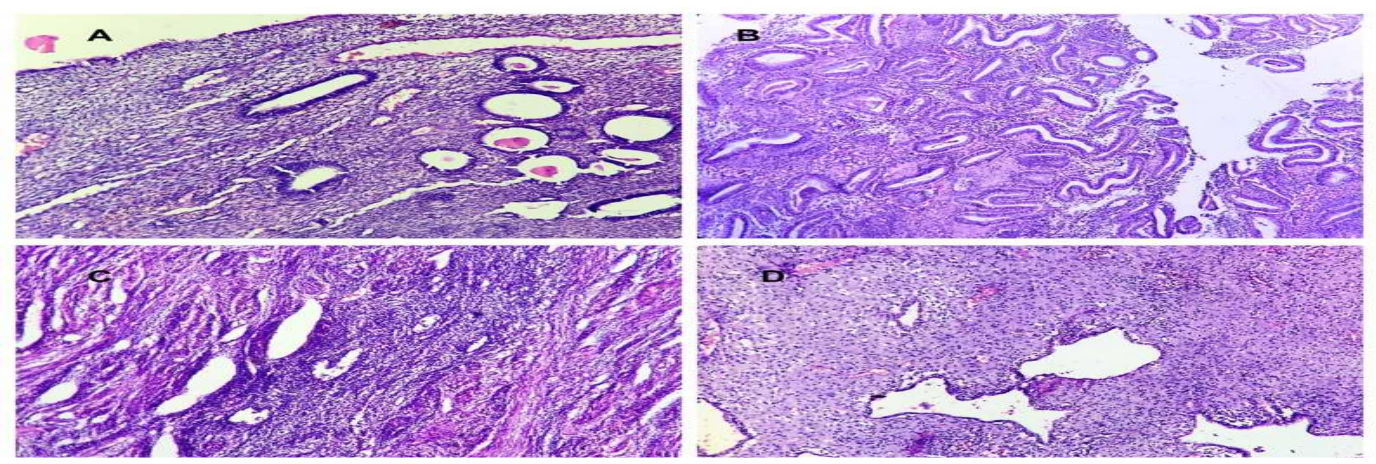

Fig.-2: Non-neoplastic lesions [H \& E: 10X]

A: Endometrial Polyp: Lining cuboidal epithelium and dilated endometrial glands surrounded by loose and oedematous stoma.

B: Simple hyperplasia without atypia: increase in number of endometrial glands without atypia.

C: Stromal Myosis: endometrial stroma without glands in the myometrium.

D: Pill endometrium: dilated and atrophic endometrial glands in decidualized stroma.

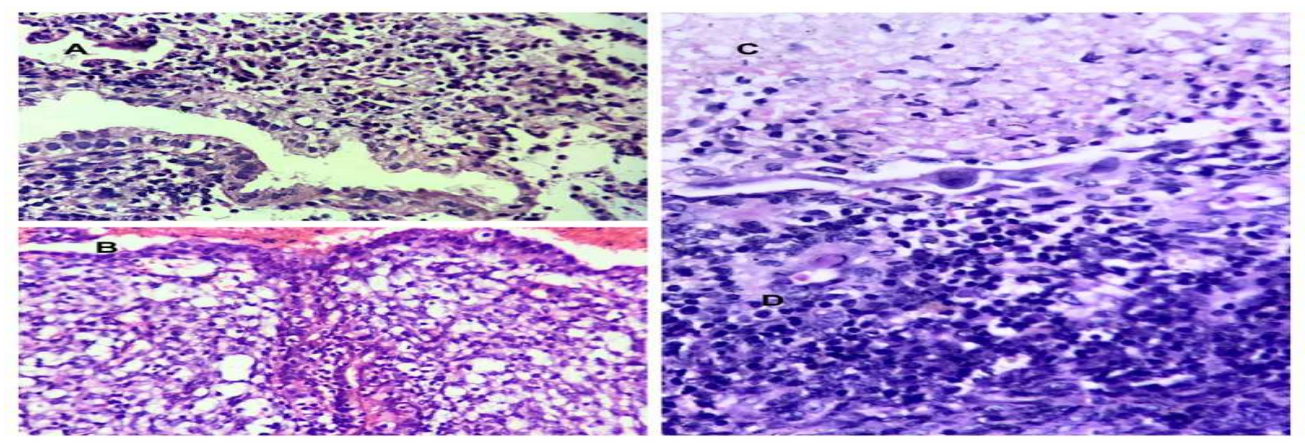

Fig.-3:Endometritis:[H\&E: 40X] 


\section{Original Research Article}

A: Acute: Endometrial gland and stroma with infiltration by polymorphs.

B: Histiocytic: Infiltration of plenty of foamy histiocytes and lymphocytes.

C: Viral: Atrophic endometrial lining epithelium with intra - nuclear viral inclusion.
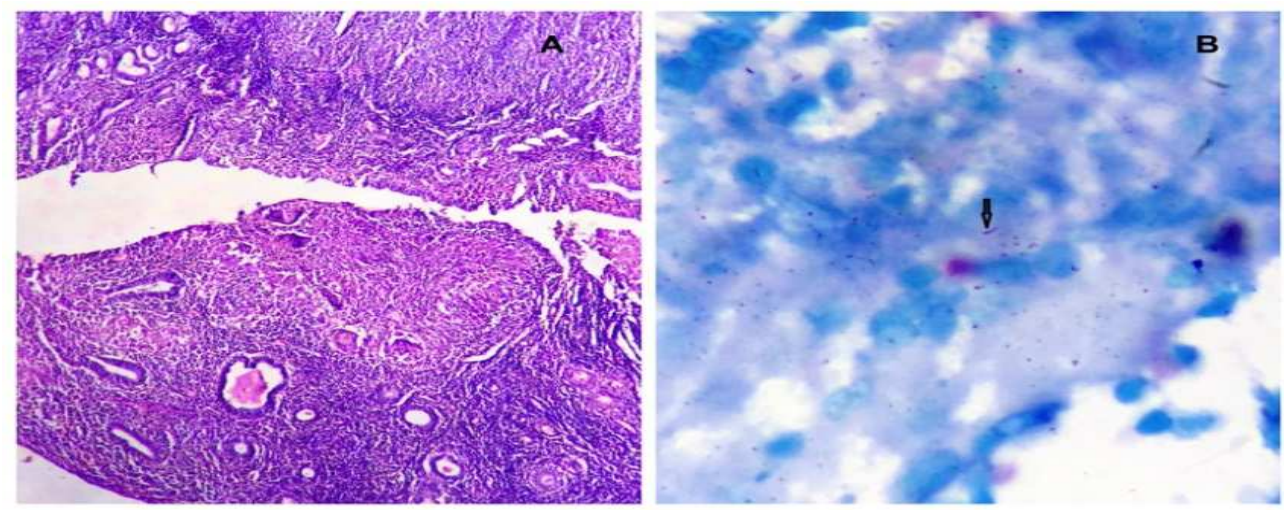

Fig.4: Tuberculous endometritis:

A: A caseating granulomas composed of epithelioid cells and langhans giant cells. [H\&E: 10X]

B: Long, slender, beaded acid fast bacillus in endometrial tissue [Fite Farraco stain: 1000X]

Stromal myosis [Fig.2:C], pill endometrium [Fig.2:D] and acute endometritis [Fig.3 A] were seen in $4(0.73 \%)$ cases respectively. Predecidual change was seen in $3(0.55 \%)$ cases \& prolonged oestrogen effect, hormonal imbalance, tuberculous endometritis [Fig.4], viral endometritis [Fig.3: C], histiocytic endometritis [Fig.3B], cysto-glandular hyperplasia was seen in $1(0.18 \%)$ case each respectively. There were $38(7.01 \%)$ cases with inadequate samples.

All the 4 cases in the benign endometrial neoplasms category were adenomyoma found in $41-50$ years age group with a common clinical presentation of raised PVB.

Table-7: Age wise distribution of malignant endometrial neoplasms:

\begin{tabular}{|c|c|c|}
\hline Age in Years & No. of Lesions & Percentage (\%) \\
\hline $41-50$ & 03 & 25 \\
\hline $51-60$ & 05 & 41.66 \\
\hline $61-70$ & 04 & 33.34 \\
\hline & $\mathbf{1 2}$ & $\mathbf{1 0 0}$ \\
\hline
\end{tabular}

Most common age group affected in malignant endometrial neoplasms was 51-60 (41.66\%) years followed by 61-70 years $(33.34 \%)$.

Table-8: Histopathological diagnosis of malignant endometrial lesions out of 542 cases:

\begin{tabular}{|c|c|c|c|}
\hline Histopathological Finding & No. of Lesions & $\begin{array}{c}\text { Total no. of endometrial } \\
\text { lesions (\%) }\end{array}$ & $\begin{array}{c}\text { Malignant endometrial } \\
\text { lesions }(\mathbf{\%})\end{array}$ \\
\hline Adenosquamous (Mixed) carcinoma & 02 & 1.53 & 16.68 \\
\hline Endometrioid Adenocarcinoma & 07 & 5.34 & 58.33 \\
\hline Serous Adenocarcinoma & 01 & 0.76 & 8.33 \\
\hline Undifferentiated Adenocarcinoma & 01 & 0.76 & 8.33 \\
\hline Mucinous Adenocarcinoma & 01 & 0.76 & 8.33 \\
\hline No. of malignant neoplastic lesions & 12 & 9.16 & 100 \\
\hline Total no. of endometrial lesions & $\mathbf{1 3 1}$ & - & \\
\hline
\end{tabular}




\section{Original Research Article}

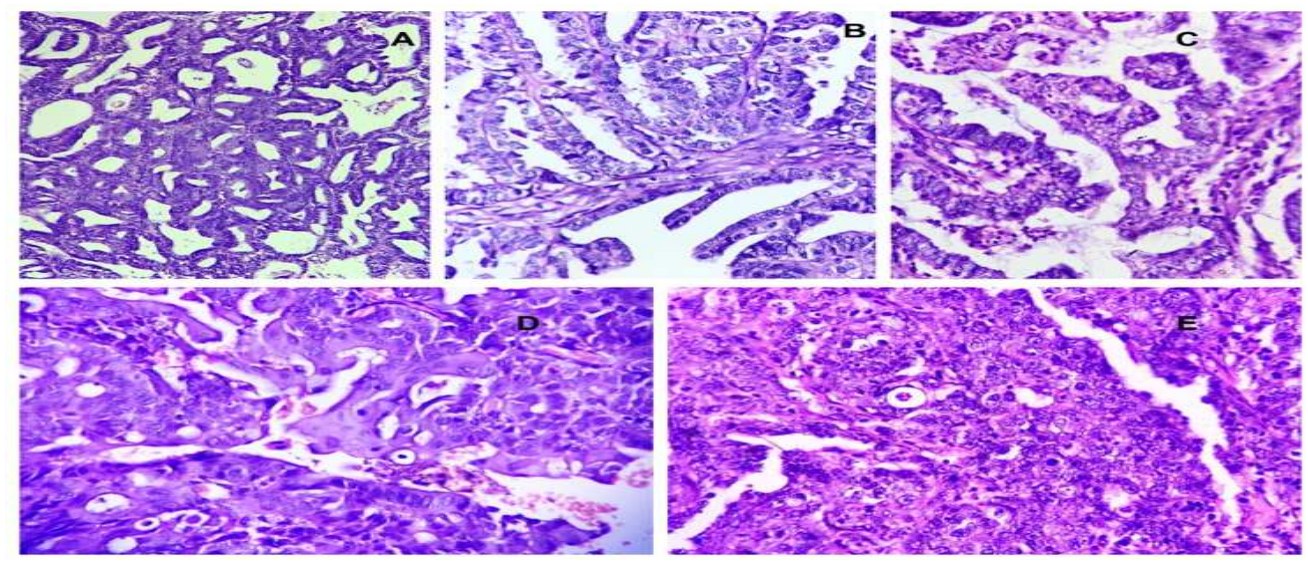

Fig.-5: Malignancies: [H\&E 40X]

A: Endometrioid adenocarcinoma: closely packed endometrial glands with back to back arrangement.

B: Papillary adenocarcinoma: Papillary arrangement of tumour cells with a fibro-vascular core.

C: Mucinous adenocarcinoma:Neoplastic endometrial glands with mucin secretions.

D: Adenosquamous carcinoma:Tumour showing aciniand sheets of keratinizing large atypical squamous cell.

E: Poorly differentiated carcinoma:Diffuse arrangement of tumour cells with hyperchromatic nuclei \& mitotic figures.

Endometrioid adenocarcinoma [Fig.5:A] was most common malignant neoplasm, comprised of 7 (1.29\%) cases followed by adenosquamous carcinoma [Fig.5:D] seen in $02(0.36 \%)$ cases and serous adenocarcinoma [Fig.5:B], undifferentiated adenocarcinoma [Fig.5:E] and mucinous adenocarcinoma [Fig.5:C] comprised $01(0.18 \%)$ case each respectively.

\section{Discussion}

The present study comprises the clinico-histopathological study of 542 endometrial cases, out of which 131 endometrial lesions (neoplastic \& nonneoplastic) were studied in the department of pathology in a tertiary care hospital for a period of two years.

Out of 542 endometrial cases, $131(24.16 \%)$ were organic lesions (115 neoplastic \& 16 non-neoplastic) and the remaining were functional ones, similar observation were found by Vaidya $S$ et al [6]. Nonneoplastic lesions were more common in the present study.

TAH was the most common surgical specimen received comprising 255 (47.05\%) samples, followed by TVH comprising $154 \quad(28.43 \%)$ samples and D\&C comprising 130 (23.98\%) samples. TAH \& TVH samples received in our department,similar observation were found in other study by Sobande A et al[7].

In the present study, the most common cyclical status was secretory phase seen in 172 (31.74\%) cases similar observation was found in other study by Vaidya et al [6] followed by proliferative phase, seen in $151(27.86 \%)$ cases. Atrophic endometrium was seen in $21.4 \%$ of cases in our study, near similar observation was found in other study by Gowari $\mathrm{M}$ et al [8]. In the present study, the most common clinical presentation was increased PVB (63.28\%), similar observation was found in other study by Kartikeyan et al [9]. This is followed by mass coming out of vagina $(24.17 \%)$, pain in abdomen $(9.60 \%)$, similar observation were found in other study by Zill-E-Huma et al[10].

In the present study, the most common age group affected in non-neoplastic endometrial lesions was 4150 years $(47.83 \%)$, similar observation was found in other study by Tiwana $\mathrm{K}$ et al [11].

Out of 542 total cases, adenomyosis was the most common non-neoplastic endometrial lesion comprising $65(11.99 \%)$, similar observation was found in other study by Kartikeyan et al [9]. This isfollowed by simple hyperplasia without atypia, comprising 18 (3.32\%) cases.Similar observation was found in other studies by Pessoa et al[12]\& Seda A et al [13].

In the present study of 542 total cases studied, there were $11(2.02 \%)$ cases of endometrial polyps, similar observation was found in other study by Surti et al [14]. 


\section{Original Research Article}

Out of 542 total cases, there was $1(0.18 \%)$ case of tuberculous endometritis with AFB positivity on $\mathrm{ZN}$ staining, similar observation were found in other studies by Bodal et al [15] and Gowari et al [8]. There was 1 $(0.18 \%)$ case of histiocytic endometritis, similar observation was found in other study by Jyotsna $\mathrm{W}$ et al [16].

Out of 16 neoplastic lesions, 4 were benign \& 12 were malignant lesions. Adenomyoma comprised of all the 4 cases of benign neoplastic lesions in the present study. Thus, malignant lesions were more common than benign lesions.Most common age group affected in benign endometrial neoplastic lesion cases was 41-50 years, while that of malignant endometrial neoplastic lesion was 51- 60 years. Out of total 12 endometrial malignancies, we found $5(41.66 \%)$ cases in the age group of 51 to 60 years, similar observation was found in other study by P. Swarna L et al [17].

Out of total 542 cases, $12(2.21 \%)$ cases of endometrial malignancies were observed, similar observation was found in other studies by Pessoa et al [12] \& Zill-EHuma et al [10]

In present study, most common type of endometrial malignancy was endometrioid adenocarcinoma comprised of 7 out of $12(58.34 \%)$ cases, which was comparable with studies done by Himel B et al[19] and Deodhar KK et al [18].

\section{Conclusion:}

In present study, non- neoplastic lesions were more common out of all endometrial lesions. Among neoplastic lesions malignant lesions were more common than benign lesions. Histopathology is important for ensuring diagnosis and deciding management, particularly for malignant diseases.

All the authors have taken near equal efforts in design and concept of this manuscript, literature search, data acquisition and analysis and in overall preparation and editing of this manuscript.

In this molecular era of diagnosis, present study still helps in ensuring diagnosis of endometrial lesions in the rural based health care institutes, tertiary health care centres where adequate facilities are not available and in similar scenario in developing countries.
Funding: Nil, Conflict of interest: None initiated, Permission from IRB: Yes

\section{References}

1. Robbins and Cotran. The Female Genital Tract, In: Pathologic Basis of Disease, $8^{\text {th }}$ edition; USA, Saunders Elsevier publisher 2010; 1024.

2. Prat J. Female Reproductive System, In Ivan Damjanov \& James Linder edited Anderson's Pathology, Vol. 2, $10^{\text {th }}$ edition; USA, Mosby publisher 2009: 2061.

3. Robbins and Cotran. The Female Genital Tract, Pathologic Basis of Disease, $8^{\text {th }}$ edition; USA, Saunders Elsevier publication 2010; 1026.

4. Juan Rosai. Female Reproductive System. Rosai and Ackerman's. Surgical Pathology. Vol.2, $10^{\text {th }}$ edition; USA, Mosby publication 2009; 1479.

5. Onuma K, Dabbs DJ, Bhargava R. Mammaglobin expression in the female genital tract: immunohistochemical analysis in benign and neoplastic endocervix and endometrium. Int $\mathrm{J}$ Gynecol Pathol. 2008 Jul; 27(3):418-25. doi: 10.1097/PGP.0b013e $31815 \mathrm{~d} 05 \mathrm{ec}$.

6. Montes M, Roberts D, Berkowitz RS, Genest DR. Prevalence and significance of implantation site trophoblastic atypia in hydatidiform moles and spontaneous abortions. Am J Clin Pathol. 1996 Apr;105 (4):411-6.

7. Sobande AA, Eskander M, Archibong EI, Damole IO. Elective hysterectomy: A Clinicopathological review from Abha Catchment area of Saudi Arabia. WAJM 2005; 24; No.1; Jan-March 2005: Page: 31-35.

8. Gowari M, Mala G, Murthy S, Nayak V. Clinicopathological Study of Uterine Leiomyomas in Hysterectomy Specimens. Journal of Evolution of Medical \& Dental Sciences; Vol. 2; Issue 46; Nov. 2013: Page: 9002-9008.

9. Kartikeyan MT, Kumar R, Thomas E. Clinicopathological study of hysterectomy among rural patients in a tertiary care center. IOSR J Dent Med Sci ver IV Volume 14, Issue 5Ver.IV(May.2015),PP 25-27. 


\section{Original Research Article}

10. Zill-E-Huma, Arjumand. A clinicopathological review of elective hysterectomies in sir Gangaram hospital. Pakistan J Med Heal Sci [Internet] 2012; 6: 970- 2.

11. Tiwana KK, Nibhoria S, Monga T, Phutela R. Histopathological audit of 373 non-oncological hysterectomies in a teaching hospital. Patholog Res Int; Sept.2014; 46: 871- 5. http://dx.doi.org/10.1155/2014/ 468715 .

12. Pessoa JN, Freitas AC, Guimaraes RA, Lima J, Dos Reis HL, Filho AC. Endometrial Assessment: When is it Necessary? J Clin Med Res. 2014 Feb;6(1):21-5. doi: 10.4021/jocmr1684w. Epub 2013 Dec 13.

13. Ates S, Ozcan P, Aydin S, Yardimci AS, Karaca N, Kilic G, Sevket O. Histopathological analysis of 422 non-oncological hysterectomies in a university hospital. J Clin Anal Med 2015; DOI: 10.4328/ JCAM. 3505.

14. Surti HB, Zaveri P, Shah CK, Shah NR. Clinicopathological study of hysterectomy cases. Biennial Journal of GAPM 2015: 1- 4. Doi: http://dx.doi.org/10.18203/2320-1770.ijrcog20170575.

15. Bodal VK, Kaur N, Das T, Bal MS, Suri AK, Kaur S: Medical correlation of the various clinical findings \& chief complains with histopathological pattern of endometrium biopsies: A study of 300 Cases. Research and reviews; Volume 3 | Issue (Supplement 3) | July September, 2014: page no. 39- 45.

16. Wader JV, Jain A, Kumbhar SS, Vhawal V. Histiocytic endometritis. Am J Case Rep. 2013 Aug 26; 14:329-32. doi: 10.12659/AJCR.889248. eCollection 2013.

17. Latha PS, Chaitanya B, Reddy S. Histopathological prognostic factor comparison of endometrial cancer patients in a tertiary hospital in India. Int $\mathrm{J}$ Reprod Contraception, Obstet Gynecol; Mar. 2014; 3 (1): 102104. Doi: 10.5455/2320-1770.ijrcog20140320.

18. Deodhar KK, Rekhi B, Menon S, Ganesh B. An audit of histopathology reports of carcinoma endometrium: Experience from a tertiary referral center. J Postgrad Med; Apr-Jun 2015; 61(2): 84-87. Doi: https: //dx. doi. Org /10.4103\% 2F0022 -3859.150 444.

19. Himel B, Dewan. Clinicopathological study of endometrium in peri-menopausal and post-menopausal women in a tertiary care hospital in eastern India. IOSR J Dent Med Sci; Feb. 2014; Vol. 13 Issue 1 ver. X: 16- 23.

\section{How to cite this article?}

Panchal S. K, Swami S.Y, Valand A.G. Histopathological study of endometrial lesions in tertiary care hospital. Pathology Updare: Trop J Path Micro 2017;3(4):368-375.doi:10.17511/jopm.2017.i4.02. 